Proc. Estonian Acad. Sci. Biol. Ecol., 2005, 54, 3, 190-209

\title{
Vertical structure of horizontal currents and vertical velocities observed off the Estonian coast using a recording Doppler current profiler
}

\author{
Ülo Suursaar*, Tiit Kullas, and Mikk Otsmann \\ Estonian Marine Institute, University of Tartu, Mäealuse 10a, 12618 Tallinn, Estonia \\ Received 27 August 2004, in revised form 10 January 2005
}

\begin{abstract}
The 3D current structure was studied in Muuga and Küdema bays using RDCP 600 current profiler data from autumn 2003 and early summer 2004. Altogether 245 hours of flow measurements from up to nine depth layers were obtained. Despite calm weather conditions (average wind speed $3.4 \mathrm{~m} / \mathrm{s}$ during the three measuring periods), the maximum horizontal current velocity reached $37 \mathrm{~cm} / \mathrm{s}$. As all the mooring sites were relatively close to the coast, downwind horizontal transport with relatively small differences over the vertical profile prevailed. The average modula of vertical velocities were between 0.47 and $0.60 \mathrm{~cm} / \mathrm{s}$, being 10-20 times smaller than the simultaneous horizontal velocities. This may suggest that at least above sloping bottoms and within the upper 10-20 m layer, rapid vertical spread of both hydrochemical and hydrobiological properties is hydrodynamically favoured. However, higher than expected measured vertical velocities indicate a disagreement with certain theoretical considerations. The possibility that the particles backscattering the RDCP signals were not neutrally buoyant should be investigated in detail in the future.
\end{abstract}

Key words: currents, vertical velocities, upwellings, RDCP, ADCP, flow measurements, Baltic Sea.

\section{INTRODUCTION}

Currents, usually considered as horizontal movements of water, have always a certain vertical structure. Actually, they also have a third, vertical component. Due to technical difficulties and relatively small values, direct measurements of vertical velocities are rare even worldwide. When measuring the horizontal currents, the current meters are traditionally deployed at certain specific depths within the water column, and each depth requires an individual instrument. The majority of current measurements in the Estonian coastal sea have been simultaneously done

\footnotetext{
* Corresponding author, ulo.suursaar@ut.ee
} 
at one depth only. Indeed, the vertical structure could be sometimes omitted, especially in shallow sea areas. However, in the presence of stratification or near the shore where slope effects, upwellings, and downwellings may exist, both the vertical structure of horizontal currents and vertical velocities should be examined.

The three-dimensional velocity structure of coastal marine systems has increasingly been investigated by means of instruments using the Doppler effect of acoustic beams only during the recent years. Initially this was done mainly in the USA (e.g. Marmorino \& Trump, 1992; Geyer, 1993), but lately also in Europe (e.g. Wewetzer et al., 1999). Acoustic Doppler current profilers (ADCPs) and recording Doppler current profilers (RDCPs) are of extreme importance in the studies of frontal structures and upwellings. The vertical structure of horizontal currents was studied using an ADCP in Muuga Bay in 1994 (Raudsepp, 1998) and in the Irbe Strait in 1995 (Lilover et al., 1998). However, the equipment used then did not allow resolving vertical velocities.

The role of vertical fluxes in the coastal marine ecosystem is rather diverse, as a large amount of energy and matter exchange between surface and deep layers occurs by the means of vertical flows of different scales. A pronounced vertical structure of both currents and biological properties could be found in convergence and divergence zones, near fronts and estuaries (e.g. Yanagi et al., 1995). These zones are usually biologically productive and economically important as well.

An ADCP also provides a good ground for interdisciplinary research of physical oceanographers and marine biologists. Besides its primary use as a current meter, interest has increased in secondary measurements of its "side-data" (van Haren, 2001). For example, ADCPs have been found to be excellent instruments for indicating the presence and behaviour of both plankton and nekton in the water column besides being used for vertical and horizontal water velocity measurements: Liljebladh \& Thomasson (2001) used the relative backscatter data of acoustic impulses for investigating the vertical migration of krill.

The aim of the present paper is to present the results of the relatively new measuring equipment in the lineup of Aanderaa Instruments called RDCP 600, deployed for the first time in the coastal waters of Estonia. We give a short overview of the instrument and the deployment setup, analyse the vertical structure of horizontal and vertical currents, and discuss possible driving mechanisms of observed fluxes and their biological implications.

\section{STUDY SITES}

An RDCP 600 was deployed within interdisciplinary field studies into two bays (Fig. 1). Muuga Bay is a partly enclosed bay of the Gulf of Finland. In a broader sense it is a $12 \times 20 \mathrm{~km}^{2}$ marine area between the Viimsi Peninsula in the west and the chain of Prangli-Aksi islands in the east (Fig. 1c). More specifically, Muuga Bay is the southwestern part of this area, while Ihasalu Bay is located in its southeastern part. Muuga Bay has a relatively wide and deep connection with 
the Gulf of Finland: a trench reaching depths of 80-100 m, comparable in depth to deep areas of the adjacent Gulf of Finland, intrudes the bay (Fig. 1c). Hence, a large part of the bay should be regarded as a hydrological constituent of the Gulf of Finland. Shallow coastal areas exhibit certain local features: in addition to the indented (natural) coastline, piers and other harbour facilities of the Muuga Port add several anthropogenic influence factors. The study site in the southern part of Muuga Bay is up to about $30 \mathrm{~m}$ deep and it is the place where the new coal terminal is being constructed.

Küdema Bay is a small $\left(4 \times 9 \mathrm{~km}^{2}\right)$ semi-enclosed bay at the northern coast of Saaremaa in the West Estonian Archipelago (Fig. 1b). It has a maximum depth of about $21 \mathrm{~m}$ in the central part, and a relatively shallow $(1-5 \mathrm{~m})$ southern part. In recent years, after rejecting the Undva, Suuriku-Kuriku, and Vaigu harbour sites, the bay is primarily known as a possible site of a deep harbour of Saaremaa. The Tamme harbour site is located at the northwestern coast of Küdema Bay,

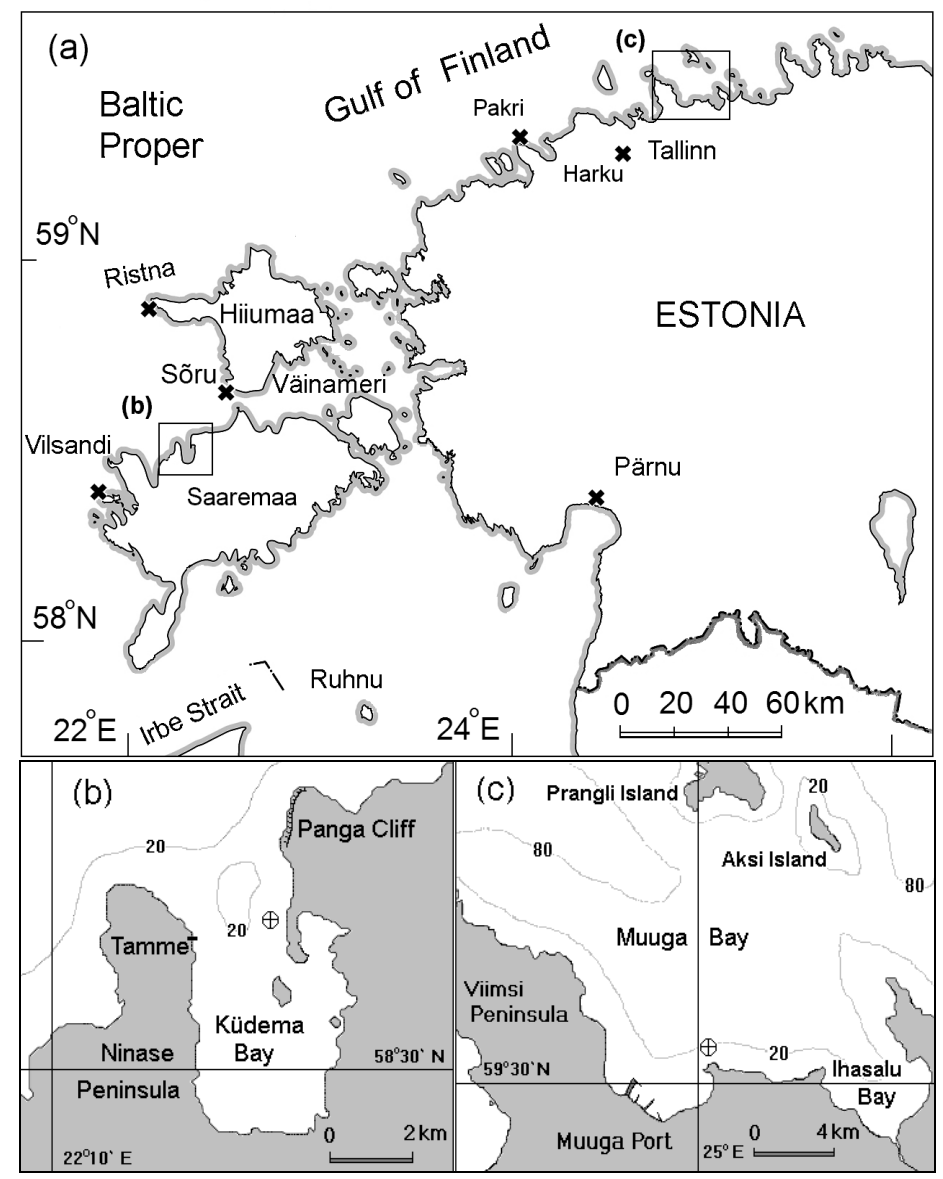

Fig. 1. Location (a) of the study areas: Küdema Bay (b) and Muuga Bay (c). 
at the Ninase Peninsula. The relations between hydrodynamic and geomorphic processes should be particularly interesting in this bay, as the eastern coast of the bay consists of a Silurian limestone cliff (the Panga Cliff, length $2.5 \mathrm{~km}$, height $21 \mathrm{~m}$ above sea level) exposed to wave erosion and currents, and a dependent accumulative distal spit (nearly $3 \mathrm{~km}$ long and up to $0.5 \mathrm{~km}$ wide) consisting of gravel and pebble (Orviku et al., 2003).

\section{MATERIAL AND METHODS \\ Overview of the RDCP equipment}

The instruments referred by different manufacturers as DCM (Doppler current meter), ADCP, or RDCP, apply the Doppler effect to measure the relative radial velocity between different objects. An instrument acts both as the source and the receiver while bouncing short pulses (pings) of acoustic energy off small particles, plankton, and air bubbles. The frequency of the backscattered signals is Doppler shifted proportional to the average radial (alongbeam) relative velocity between the scatterers and the transducers. Usually three or four transducers are used in order to calculate velocity components. Four beams are simultaneously pinged by transducers with a $25^{\circ}$ slant angle in the RDCP 600 (Fig. 2).

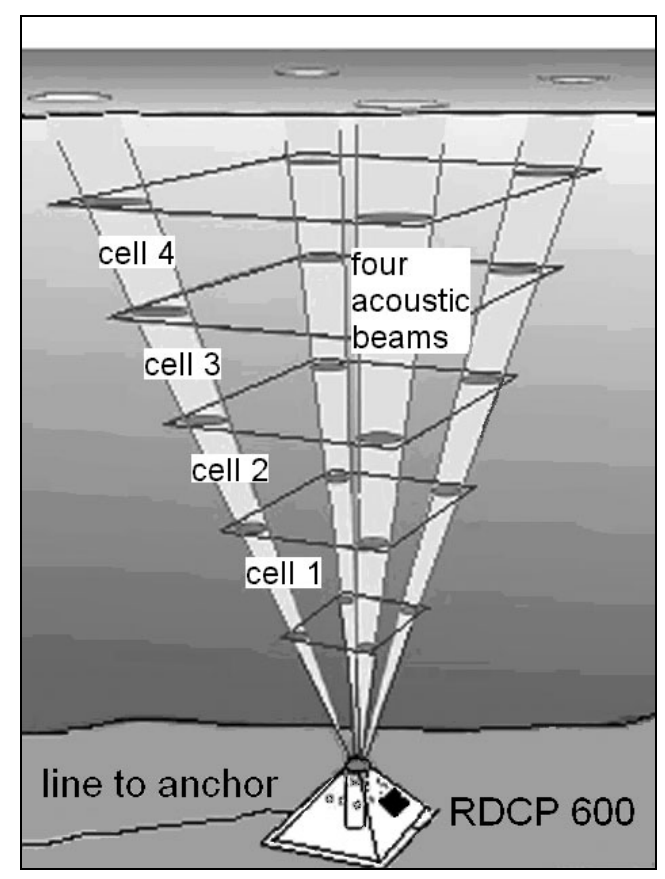

Fig. 2. Scheme of the RDCP 600 installation on the seabed using a bottom frame. Four transducer beams scanning four depth intervals are shown. 
The RDCP 600 is the most advanced product of Aanderaa Instruments AS to date. It has been designed for use in bottom-mounted installations, but it can be used in string moorings, downward facing surface buoys, and ship-mounted configurations as well. The RDCP 600 is a $600 \mathrm{kHz}$ medium-range self-recording acoustic Doppler current profiler, which employs a high-performance, low-power digital signal processing system, 32-bit embedded central processing system, and Windows $\mathrm{CE}$ embedded real-time operating system. An advanced beam compensation system compensates for instrument tilt and provides a true horizontal current reading even when the instrument is not positioned strictly vertically. Vertical component resolving depends particularly on the precise positioning of the instrument.

The water column is divided into uniform segments called depth cells or bins. The cell size range can be between 1 and $10 \mathrm{~m}$ (down to $0.1 \mathrm{~m}$ steps) and each cell is comparable to a single current meter. The maximum number of cells is 150 , but this would require a minimum of $155 \mathrm{~m}$ sea depth: $1 \mathrm{~m}$ for each cell plus 1-2 $\mathrm{m}$ "blind" distance between the instrument and the first cell, plus 2-3 surface metres, which are "contaminated" by wave motions. Actually a $2 \mathrm{~m}$ cell with $50 \%$ cell overlap is recommended by the manufacturer for impoving data quality. Doubling either the cell size or the ping length yields an improvement in statistic noise of the square root of two. Also increasing the ping count will lower the noise level.

In addition to measuring currents, our RDCP 600 is equipped with temperature, turbidity, and conductivity (i.e. salinity) sensors, as well as a high accuracy quartz based pressure sensor, which enables to measure the depth of the instrument (i.e. relative sea level variations) and wave parameters such as significant wave height, maximum wave height, peak period, mean period, wave steepness, wave spectrum, etc. Naturally, these sensors provide only one set of measurements: either in contact with the instrument (temperature, salinity, turbidity) or in relation to the sea surface (sea level, waves). The recording interval could be set at different periods up to an option of "only record part of each day".

Vast data output includes not only primary time series listed briefly above, but also (optional) time series of signal strength, standard deviations of each beam, and information about the instrument condition (direction, pitch, roll, battery voltage, etc.). The raw data pre-processed by the special software could be stored either on a multi-media card (MMC) or transmitted to the shore by means of a cable.

\section{Deployment setup and data processing}

The self-contained bottom-mounted RDCP 600 was deployed in three periods in two bays of the Estonian coastal sea (Table 1). The Muuga Bay deployment site (Fig. 1c) was about $1 \mathrm{~km}$ off the newly constructed coal terminal. In Küdema 
Table 1. RDCP 600 measurements in Muuga and Küdema bays

\begin{tabular}{|c|c|c|c|c|c|c|}
\hline $\begin{array}{l}\text { Period } \\
\text { No. } \\
\end{array}$ & $\begin{array}{l}\text { Deployment } \\
\text { coordinates }\end{array}$ & $\begin{array}{c}\text { Depth, } \\
\mathrm{m}\end{array}$ & $\begin{array}{l}\text { Start and end } \\
\text { (Local Time) }\end{array}$ & $\begin{array}{c}\text { Duration, } \\
\mathrm{h}\end{array}$ & Layers & $\begin{array}{c}\text { Interval, } \\
\text { min }\end{array}$ \\
\hline \multirow[t]{2}{*}{1} & $59^{\circ} 30.8^{\prime} \mathrm{N}$ & 14 & 05.09.03 12:10 & 12 & 9 & 10 \\
\hline & $25^{\circ} 00.5^{\prime} \mathrm{E}$ & & 05.09.03 23:50 & & & \\
\hline \multirow[t]{2}{*}{2} & $59^{\circ} 30.8^{\prime} \mathrm{N}$ & 12 & $27.10 .0319: 00$ & 214 & 6 & 10 \\
\hline & $25^{\circ} 00.5^{\prime} \mathrm{E}$ & & 05.11.03 17:00 & & & \\
\hline \multirow[t]{2}{*}{3} & $58^{\circ} 31.1^{\prime} \mathrm{N}$ & 10 & 01.06.04 00:00 & 19 & 5 & 10 \\
\hline & $22^{\circ} 16.6^{\prime} \mathrm{E}$ & & 01.06.04 19:41 & & & \\
\hline
\end{tabular}

Bay the instrument was moored on the opposite side of the planned Tamme deep harbour site, close to the geomorphically interesting distal spit (Fig. 1b). A pilot boat of Tallinn Port was used in Muuga Bay, and the fishboats Ann-Mari and Johanna were used in Küdema Bay. The instrument was deployed to the seabed using a bottom mounted frame supporting extended battery capacity (Fig. 2). The frame was connected to an anchor some $100 \mathrm{~m}$ away, no surface float was directly attached either to the instrument or the anchor. Two small surface buoys were pitched nearby.

As the depths of the mooring sites were small, the number of layers (cells) with accurate measurements was between 5 and 9. The measurements also included some near-surface cells, but due to large standard deviations they were discarded. The current data were dubbed by "surface referred" depth cells as well, which provide an opportunity for quality checking.

The first and the third deployment period were actually longer than the merely 12 or 19 hours as shown in Table 1. In the first case the instrument was unfortunately torn on its side, possibly in the course of an international mine-seeking campaign on Muuga Bay. The instrument continued to record hydrological parameters, but thereafter the current and wave data were unusable. During the third deployment period (in Küdema Bay) the instrument was vandalized.

We used $2 \mathrm{~m}$ cell size with $50 \%$ overlap, hence " $11 \mathrm{~m}$ depth" actually means 10-12 m depth interval, " $10 \mathrm{~m}$ depth" means 9-11 m, etc. Thus, the data from two adjacent cells are technically somewhat correlated. Each current record included the average value of 300 pings (or individual measurements). A single ping has statistical noise of $9 \mathrm{~cm} / \mathrm{s}$ ( $2 \mathrm{~m}$ cell size, $2 \mathrm{~m}$ ping length), the setup used by us (300 pings) yielded estimated standard noise levels as low as $0.58 \mathrm{~cm} / \mathrm{s}$ for the horizontal currents and $0.29 \mathrm{~cm} / \mathrm{s}$ for vertical currents.

Hence, we obtained measurements from a total of $245 \mathrm{~h}$, but due to a multitude of recording layers and large number of parameters, the data amount is rather large. Mainly properties of the current velocity data are discussed in this paper. 


\section{RESULTS AND DISCUSSION}

\section{Meteorological forcing data and hydrological conditions}

The weather conditions during all the three surveys were relatively calm (the data of the stormy periods were unfortunately lost). The meteorological conditions of the Muuga Bay surveys were described using the data from the Pakri meteorological station, as the quality of these is more suitable for the marine areas than of those of the Harku station. For the Küdema survey, data from the Vilsandi meteorological station were used. Both stations are operated by the Estonian Hydrological and Meteorological Institute and they provide hourly wind data.

The average wind speed during the first survey (5 September 2003) was $2.1 \mathrm{~m} / \mathrm{s}$ $(\max 2.8, \min 0.9 \mathrm{~m} / \mathrm{s})$. Winds from the west and north-west prevailed. The average wind speed during the second, longest deployment period (27 October5 November 2003$)$ was $3.7 \mathrm{~m} / \mathrm{s}(\max 7.5, \min 0.2 \mathrm{~m} / \mathrm{s})$ on the Pakri Peninsula. Southern directions (W, SW, S, SE) prevailed (Fig. 3a). The third survey (1 June 2004) had an average wind speed of $1.9 \mathrm{~m} / \mathrm{s}(\max 3.5, \min 0 \mathrm{~m} / \mathrm{s})$ at Vilsandi, displaying mainly winds from the north-west. All these average wind speed values are substantially below the long-term average wind speeds on Estonian coasts $(4-7 \mathrm{~m} / \mathrm{s})$. Consequently, the wave activity was also quite low. The highest waves at the mooring site were measured on the first two days of the second period. The maximum wave height reached $1.4 \mathrm{~m}$ and significant wave height $0.9 \mathrm{~m}$ (Fig. 3c). The first and the third period had wave heights below $0.4 \mathrm{~m}$.

As for usefulness of wave measurements, simultaneous registration of both currents and waves poses somewhat contradictory requirements for mooring setup. Current measurements require a depth of at least 5-6 $\mathrm{m}$ and, for better utilization of multi-layer measurement capacity of the RDCP, even much deeper moorings are recommended. The wave measurements, on the contrary, require instrument depths less than ca 10-15 m. In general, sampling frequency of $2 \mathrm{~Hz}$ allows studying waves with periods more than $1 \mathrm{~s}$. However, the dynamic pressure caused by waves with short wave periods is damped rapidly with depth. For example, wave periods below ca $4 \mathrm{~s}$, which comprise a major part in the shallow water wave spectrum, are missing (cut off) below 10-15 $\mathrm{m}$. The best wave measurements are threfore possible in relatively deep water (say, at least 20 $30 \mathrm{~m}$ ) locations with subsurface $(2-5 \mathrm{~m})$ moorings, which, on the other hand, give only very little information about currents. In general, the instrument is capable of giving simultaneous information on both, but it is still better to concentrate either on waves or currents.

According to the Pärnu tide gauge data the sea level fluctuated between +10 and $+20 \mathrm{~cm}$ during the first survey, between -20 and $+50 \mathrm{~cm}$ during the second (longest) survey, and between +5 and $-10 \mathrm{~cm}$ during the third survey. As the sea level at Pärnu has the strongest reaction to the wind (Suursaar et al., 2003), the range of the sea level variations in our study sites is likely much smaller. 

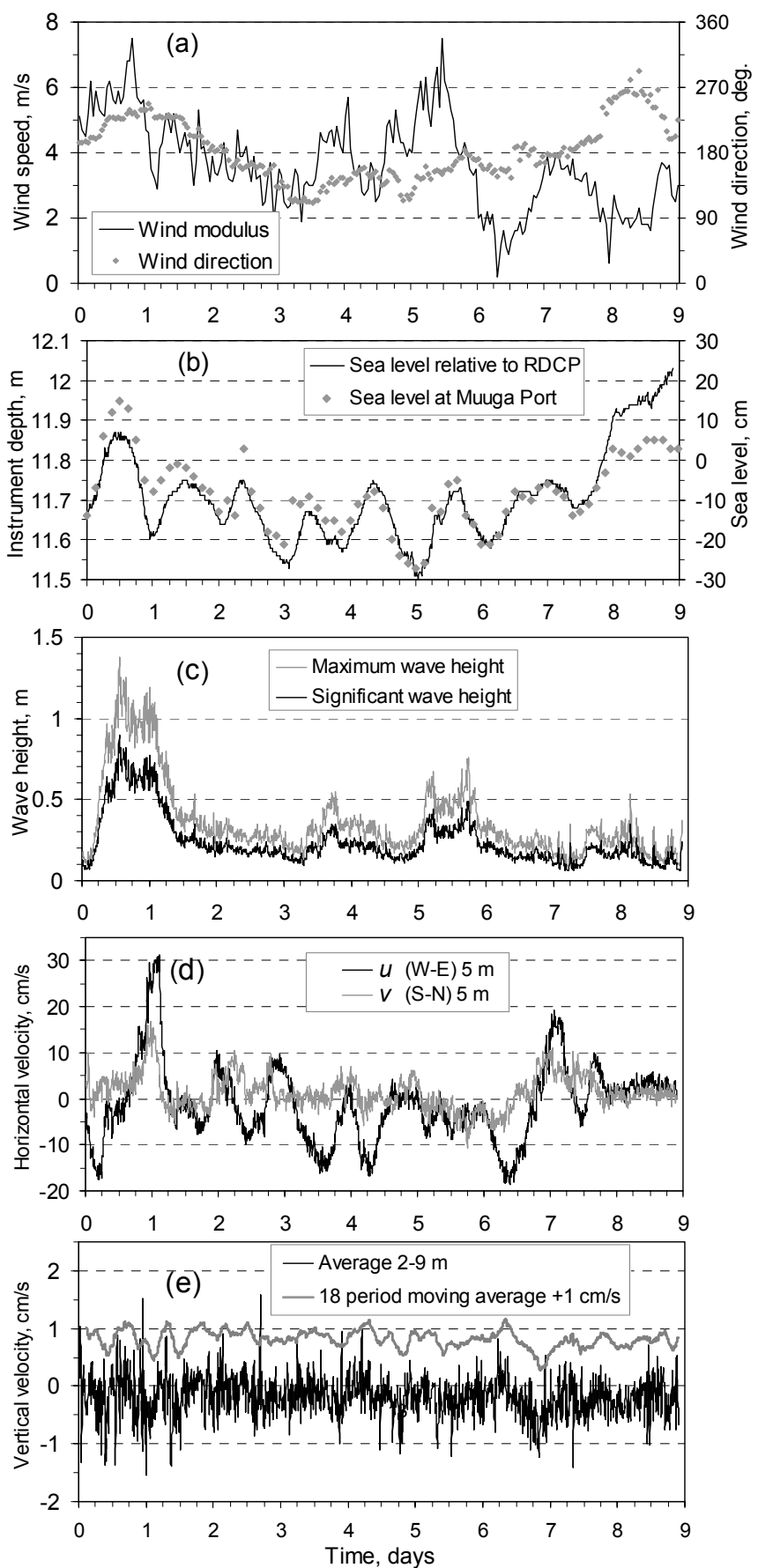

Fig. 3. Time series of hourly wind speeds and directions at the Pakri meteorological station (a); relative sea-level variations measured as "instrument depth" together with eight-daily sea-level measurements at Muuga Port (b); RDCP-measured wave heights (c); horizontal current velocity components $u$ and $v(\mathrm{~d})$; and vertically averaged vertical velocities together with $3 \mathrm{~h}$ moving averages (shown with $1 \mathrm{~cm} / \mathrm{s}$ offset) (e) in Muuga Bay on 27 October-5 November 2003. 
Figure $3 \mathrm{~b}$ shows variations in eight-daily sea level measurements at the Muuga Port together with relative to RDCP sea level measurements. Differences, which are quite small, appear mainly due to measurement locations at different sides of the bay (Fig. 1c). While the RDCP output is much more detailed, it is not fixed to levelling benchmarks like tide gauges are.

Both the salinity and water temperature ought to have certain vertical structure in the bays under discussion. The thermohaline conditions during the first and the third survey could be described using the data provided by the RDCP 600 only. The water temperature dropped markedly - from 11.2 to $4.7^{\circ} \mathrm{C}$ during the $12 \mathrm{~h}$ of the first survey. It shows large spatial inhomogeneities transposed by horizontal advective flows. The temperature variation during the third survey was modestly $1{ }^{\circ} \mathrm{C}$ (between 9.5 and $10.5^{\circ} \mathrm{C}$ ).

A more extensive hydrological survey was performed during the second period. The water temperature measured by the RDCP 600 at the mooring site stayed between 6.1 and $7.1^{\circ} \mathrm{C}$ during the whole 9-day period. Apparently the surface layer was well mixed during the autumn storms and cooling. Also the CTD profilings showed that the water column was rather homogeneous down to about $23 \mathrm{~m}$, followed by the thermo-halocline between 23 and $26 \mathrm{~m}$ with salinity increment of 0.8 and temperature change of $2{ }^{\circ} \mathrm{C}$ (Tamsalu, 2003). Also a dumping event associated with harbour construction work near the measurement site is worth mentioning here. It caused off-scale (above $22.2 \mathrm{ftu}$ units) records of the RDCP turbidity sensor throughout the period from 27 October to 5 November 2003 compared to $1-1.5 \mathrm{ftu}$ values during the 5 September 2003 survey. The turbidity sensor attached to the CTD sonde additionally recorded 20-40/50-80 ftu in upper/nearbottom layers on 27 October, and 10-20/20-60 ftu on 5 November, indicating prevalence of deposition of suspended matter between these dates.

\section{Vertical structure of velocity components}

The general character of current speed variations during the second period is shown in Fig. 3d, e. The highest values of horizontal velocity modula $(36.6 \mathrm{~cm} / \mathrm{s})$ were found in the near-surface layer $(2-4 \mathrm{~m})$ on 28 October, when the wind speed was also the highest $(7.5 \mathrm{~m} / \mathrm{s})$ for all the measuring periods. The discarded (mainly due to questionable vertical velocity values) 1-3 and 0-2 m layers showed only slightly higher (up to $39 \mathrm{~cm} / \mathrm{s}$ ) horizontal velocities. The average horizontal velocities were between 5.4 and $8.5 \mathrm{~cm} / \mathrm{s}$ during the different measuring periods (Table 2).

Figures 4 and 5 include a set of progressive vectors, showing the resultant water (or air) movement during the periods under discussion both in horizontal (Fig. 4) and vertical planes (Fig. 5). The vectors are summed so that each current vector starts from the end of the previous one. The certain order or "natural- 
Table 2. Average horizontal velocity, vertical velocity, and average vertical velocity modulus $(\mathrm{cm} / \mathrm{s})$ in different depth layers during the first (1), second (2), and third (3) measuring period (see also Table 1)

\begin{tabular}{l|rr|r|r|r|r|r|r|r}
\hline \multirow{2}{*}{$\begin{array}{c}\text { Depth, } \\
\mathrm{m}\end{array}$} & \multicolumn{3}{|c|}{ Horizontal velocity } & \multicolumn{3}{c|}{ Vertical velocity } & \multicolumn{3}{c}{ Vertical modulus } \\
\cline { 2 - 10 } & 1 & 2 & 3 & 1 & 2 & 3 & 1 & 2 & 3 \\
\hline \multirow{2}{*}{} & & & 6.6 & & & -0.27 & & & 0.47 \\
3 & 6.0 & 10.9 & 6.3 & 0.10 & -0.30 & -0.34 & 0.33 & 0.46 & 0.57 \\
4 & 6.1 & 8.1 & 5.4 & 0.08 & -0.31 & -0.33 & 0.33 & 0.47 & 0.57 \\
5 & 6.8 & 7.8 & 4.7 & 0.17 & -0.32 & -0.21 & 0.40 & 0.47 & 0.47 \\
6 & 8.2 & 7.2 & 4.2 & 0.28 & -0.30 & 0.10 & 0.43 & 0.46 & 0.57 \\
7 & 9.6 & 6.8 & & 0.42 & -0.17 & & 0.51 & 0.44 & \\
8 & 10.4 & 6.3 & & 0.52 & 0.27 & & 0.55 & 0.52 & \\
9 & 10.5 & & & 0.78 & & & 0.79 & & \\
10 & 10.0 & & & 0.93 & & & 0.94 & & \\
11 & 9.3 & & & 1.09 & & & 1.09 & & \\
\hline Mean & 8.5 & 7.9 & 5.4 & 0.49 & -0.19 & -0.21 & 0.60 & 0.47 & 0.53
\end{tabular}

looking sequence" in both the horizontal and vertical progressive vectors reflects (in addition to technical correlation of each two or three overlapping adjacent cell values) also the good quality of measurements.

Comparison of the progressive atmospheric and water flow vectors (Fig. 4) showed that the water flow conditions in both bays mostly depend on the local wind. Compared with wind vectors, the current vectors tend to turn left in Muuga Bay (Fig. 4a-d), which probably shows the influence of the coast in south and south-east. The curves show in general similar behaviours, at least there are no flows with opposite directions in different layers. This is due to small mooring depths (10-14 m), which generally cover the mixed upper layer. The magnitudes, however, are rather different (see also Table 2). Considering both the horizontal (Fig. 4) and vertical (Fig. 5) sections, the layer differing the most from the others is the uppermost $(2-4 \mathrm{~m})$ layer for the first period, the lowest $(7-9 \mathrm{~m})$ for the second period, and also the lowest $(5-7 \mathrm{~m})$ layer during the third period. Though in our case they were the marginal layers measured by the instrument, in nature they had at least one neighbouring layer within the blanking region of the instrument.

Considering the weak $(0.9-2.8 \mathrm{~m} / \mathrm{s})$ winds of the first period, very rapid nearbottom temperature drop, and larger near-bottom velocities compared to the nearsurface ones, there had to be an advective flow in the lower layers (Fig. 4a). As the direct wind stress could not be the major forcing for this advection, the hydrodynamic situation in the study site should have reflected certain subbasin-wide circulation features. During the second period the direct wind forcing was quite evident because of larger wind speeds. In addition to this apparent wind-driven 

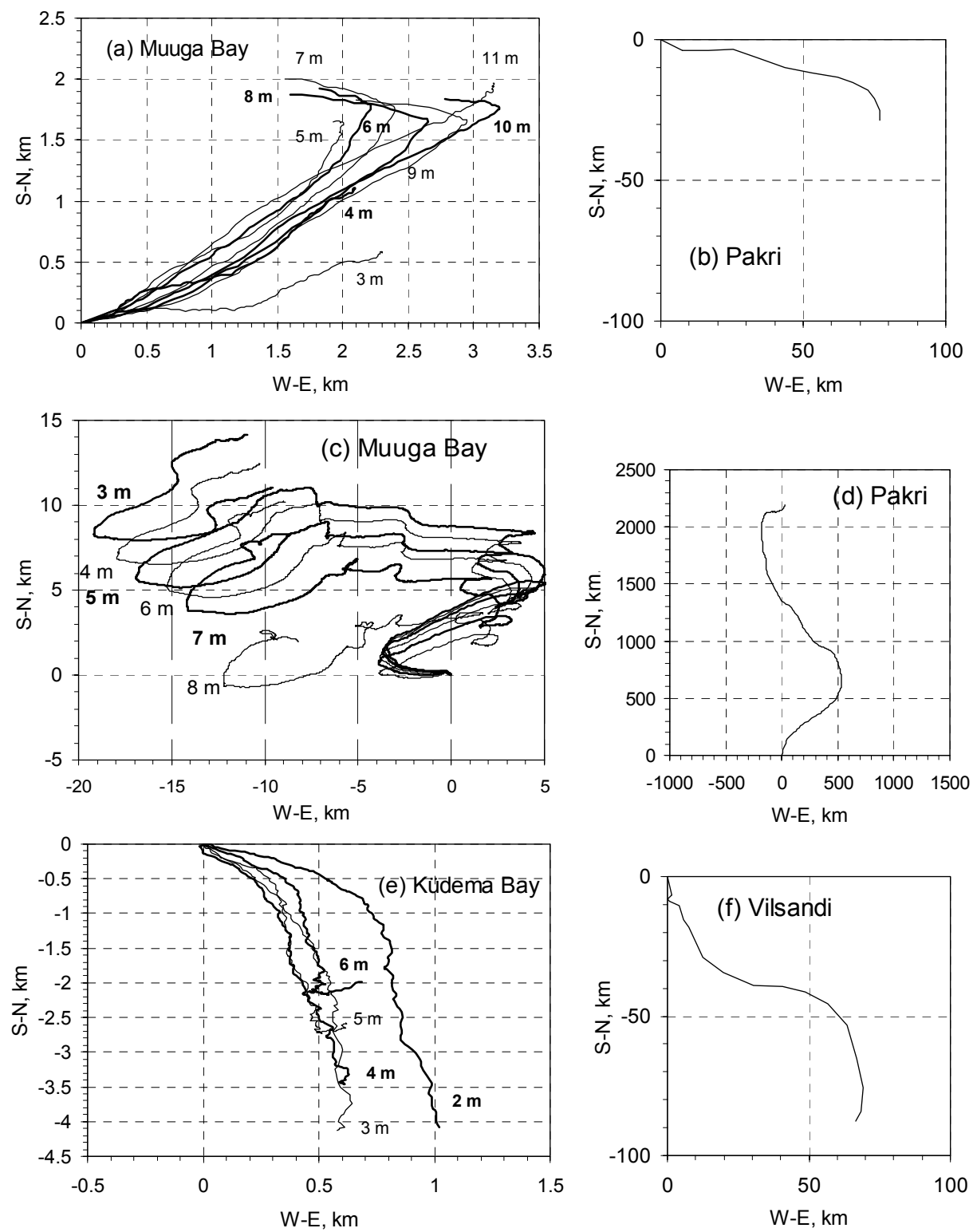

Fig. 4. Progressive vectors of horizontal current velocities in different layers during the three measuring periods (a: 05.09.2003, c: 27.10.-05.11.2003, e: 01.06.2004; see also Table 1). Corresponding progressive wind graphs are shown on $\mathrm{b}, \mathrm{d}$, and $\mathrm{f}$. 
flow, certain subbasin-wide circulation component is present again (Fig. 4c). In Küdema Bay the direct influence of the local wind is the most evident (Fig. 4e).

Raudsepp (1998) argued that under calm weather conditions the circulation in Muuga Bay is largely controlled by the estuarine circulation of the Gulf of Finland as a whole. It means enhanced seaward (westward) advection of "riverine" water, compensating for the slow deep inflow of saltier water, general anticyclonic flow through the bay in the upper layer, and the cyclonic flow pattern in the lower layer. Also, according to the modelling study on the mean circulation of the Gulf of Finland (Andrejev et al., 2004), the residual eastward transport component prevailed in Muuga Bay both in the surface $(0-2.5 \mathrm{~m})$ and subsurface (2.5-7.5) layers. The circulation in partly mixed estuaries is usually expressed as the sum of three modes: wind stress mode, river discharge mode, and gravitational convective mode. River discharge is important for the Gulf of Finland as a whole, and especially for its eastern section, but it is unimportant for Muuga Bay. We found in our relatively near-coast study sites a vertically rather homogeneous alongshore flow (or coastal jet) in response to the alongshore wind stress even when the wind forcing was moderate or weak. In our case the wind-driven flow was not modified by the typical estuarine flow pattern of the whole Gulf of Finland, but by a certain subbasin-wide (more regional) component. As all the three mooring sites were relatively close to the coast, downwind horizontal transport with relatively small vertical differences prevailed. In the semi-enclosed subbasins a compensatory upwind flow should exist in the deeper off-shore region, forming distinctive basin-wide circulation cells. Also (horizontal) baroclinic components due to autumn mixing, cooling, and changes in thermohaline stratification, could be considered.

Up- and downwellings are relatively common phenomena in the coastal areas (see e.g. Ennet et al., 2000; Sobarzo et al., 2001). In statistical sense downwellings are expected to prevail both along the northern coast of Saaremaa and in the region of Muuga Bay (Myrberg \& Andrejev, 2003). Though both our measuring sites were located near the coast and above bottom slopes, it is somewhat difficult to explain the observed vertical fluxes (Fig. 5a-c) merely as upwellings or downwellings; a bit stronger and more persistent winds are needed for that. If there were stronger winds, downwelling should have existed during the first period and upwelling during the third period. Upwelling of nearbottom water should have prevailed during the second period as well, as the wind was predominantly directed away from the coast. Thus, the vertical velocities reflect either the features of the overall three-dimensional (3D) flow scheme of the subbasin, or some local coastal slope effects.

Out of the total of 8924 vertical velocity readings, $88.6 \%$ of the absolute values were below $1 \mathrm{~cm} / \mathrm{s}$. Altogether only 21 readings $(0.002 \%)$ were above $2 \mathrm{~cm} / \mathrm{s}$ absolute value (see also Fig. $5 \mathrm{~d}-\mathrm{f}$ ). The average modulus of vertical velocities (i.e. the velocity magnitude not depending on direction) was between 

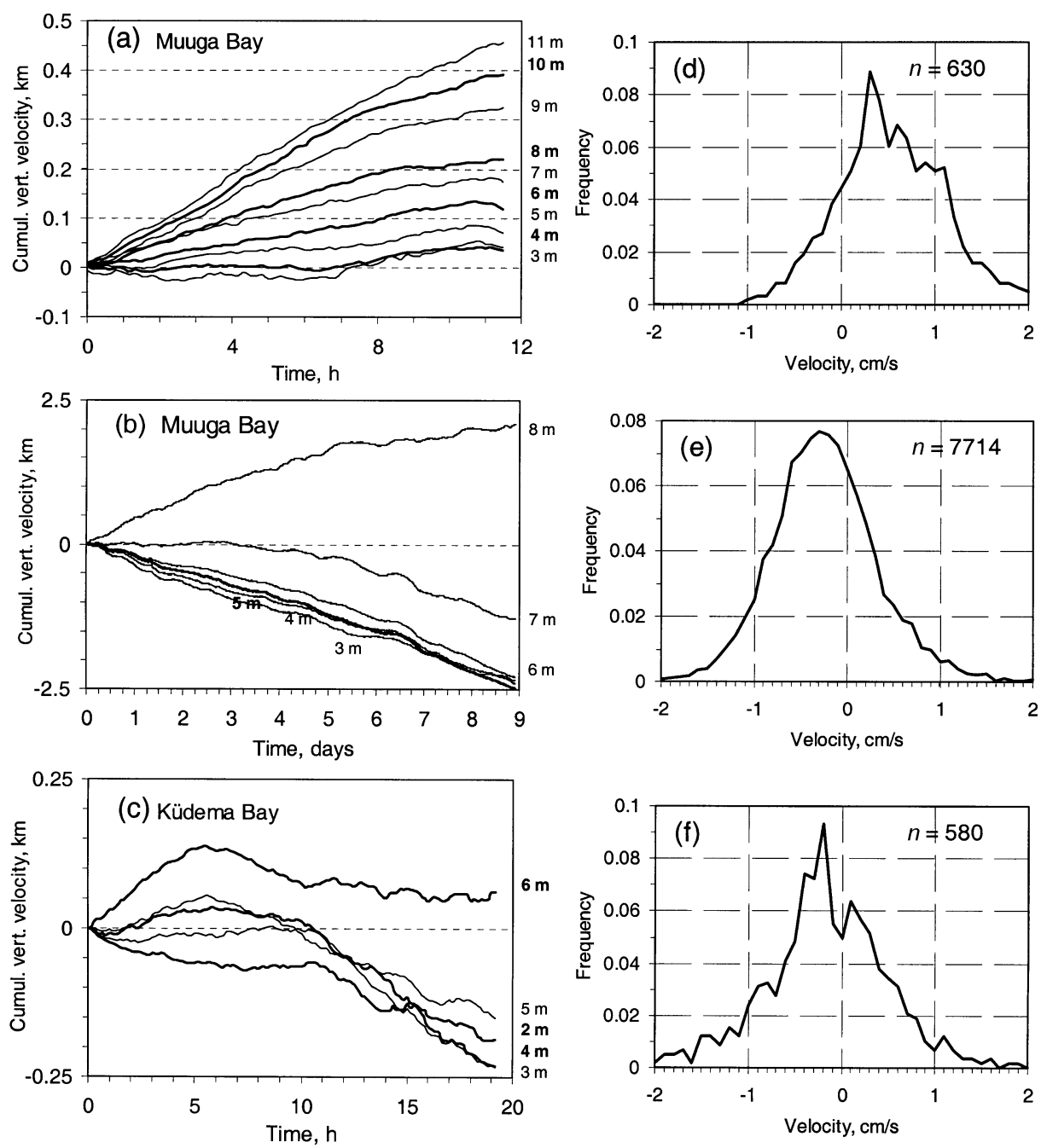

Fig. 5. Cumulative graphs of vertical velocity components in different layers during the three measuring periods ( $a, b$, c; periods same as in Fig. 4). Corresponding empirical frequency distributions of the vertical velocity data $(\mathrm{d}, \mathrm{e}, \mathrm{f}): \mathrm{n}$ - total number of the velocity readings in the period.

0.47 and $0.60 \mathrm{~cm} / \mathrm{s}$ in all the three measuring periods, while the average velocities (considering also direction) were between -0.21 and $+0.49 \mathrm{~cm} / \mathrm{s}$ (Table 2). These values exceed only slightly the statistical noise level $(0.29 \mathrm{~cm} / \mathrm{s})$ of the vertical velocity measurements in our measuring setup. The values, however, are still quite high, being just 10-20 times lower than the horizontal velocities.

Vertical velocities in the surface, calculated as derivatives from the sea-level changes, show values up to $0.002 \mathrm{~cm} / \mathrm{s}$ (Fig. 6). Taking into account the up to $10^{\circ}$ 


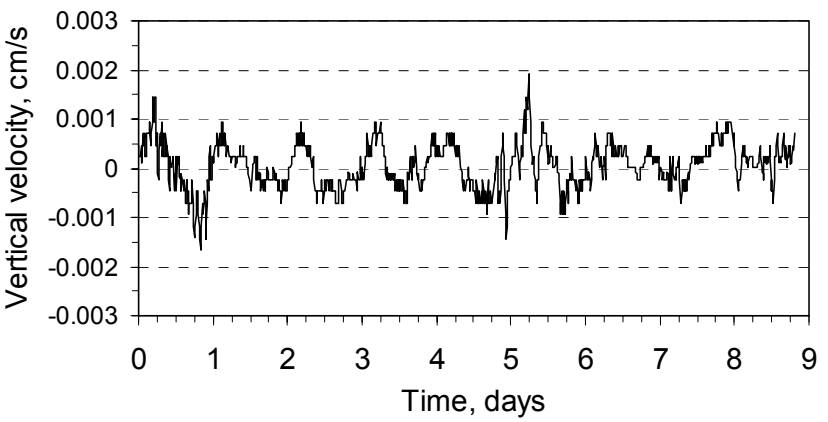

Fig. 6. Sea surface vertical velocities calculated from the sea level changes in Muuga Bay on 27 October-5 November 2003 (see also Fig. 3b).

bottom slope and $10 \mathrm{~cm} / \mathrm{s}$ horizontal current velocity, the vertical velocities due to the sloping bottom of Muuga Bay were estimated at $0.01-0.08 \mathrm{~cm} / \mathrm{s}$. These estimates for the exact surface and nearbottom layers, however, do not technically exclude the existence of different vertical velocity structures in between. The convergence of streamlines in the vertical section must be just compensated for by the divergence in the horizontal section, and vice versa. However, in the condition of modest external forcing, the physical reason for such values remains unclear. Certain small-scale processes such as thermohaline convection or Langmuir circulation, could yield vertical velocities of such magnitude, but RDCP equipment is not capable of resolving them. Moreover, due to the lateral shift of circulation cells, Langmuir circulation cannot produce systematic upward or downward flow for certain longer periods in a fixed marine point.

Vertical velocities estimated by Raudsepp (1998) from continuity equations were between 0.02 and $0.06 \mathrm{~cm} / \mathrm{s}$ in Muuga Bay, though also in calm wind conditions. Yanagi et al. (1995) estimated vertical velocities as high as up to 0.1$0.2 \mathrm{~cm} / \mathrm{s}$ in a hydrodynamically active convergence-divergence zone associated with a tidal front in the Seto Inland Sea, Japan. Doppler effect-based direct measurements yield generally much higher vertical velocities than considered traditionally. For example, velocities as high as around $10 \mathrm{~cm} / \mathrm{s}$ were measured in the hydrodynamically active Tay Estuary in Scotland by Wewetzer et al. (1999). Unusually high vertical velocities and "upsloping" phenomena are suggested also by non-hydrostatic 3D hydrodynamic models (e.g. Deleersnijder, 1989; Hervouet, 2003; Zalesny et al., 2004).

If we trust the surprisingly high measured vertical velocities, we can conclude that at least above the sloping bottom and within the upper, relatively mixed layer, rapid vertical spread of both hydrochemical and hydrobiological properties is not hydrodynamically restricted. If we proclaim them as theoretically "suspicious" (especially bearing in mind the relatively calm forcing conditions), the question about the origin of these values arises. The graphs (Figs. 4-5) display a sufficiently 
strong "order" and an evident sequence for being just random errors. There is no strong evidence of a certain systematic error either, as different expeditions showed different "orders" (Figs. 4-5). One mechanism that could lead to such kind of systematic error components is the influence of backscattering particles, that is air bubbles, plankton, or suspended matter that can move up- or downwards regardless of vertical water movements. Regarding the RDCP, it is strictly assumed that these particles are neutrally buoyant and they move at the same velocity as the water. However, background data referred earlier suggested that massive settling of the matter suspended due to dumping prevailed during the second measuring period. This anthropogenic event could have affected the vertical velocity measurements. However, there was no direct evidence of similar events during the first and the third measuring periods. Thus, the explanation remains hypothetical and the disagreement between direct measurements and indirect velocity estimations should be investigated in the future.

\section{Fine structure and time series analysis}

A selection of records showing a fine structure of horizontal and vertical velocities are presented in Fig. 7. While the horizontal velocities exhibit both a visible meso-scale variability component and certain synchronous small-scale behaviour of time series, the vertical velocities show rather noisy small-scale variability. A $20-30$ min periodicity seems to be present in the records: the velocity fluctuations do not seem random.

In order to find out whether this "oscillation" period consisting of 3-4 subsequent readings is a really existing component or just an artefact, we performed spectral analysis. Figure 8 shows some examples of non-smoothed Fourier spectra of horizontal velocity components $u$ and $v$ (Fig. 8a-d) and vertical velocities (Fig. 8e-f). In addition, spectra of salinity and sea-level data for the same period are presented in Fig. 8g, h, showing spectral decay following the so-called $-5 / 3$ law. These spectra confirm a good quality of such measurements as opposed to the noisy vertical velocity spectra.

Within the analysed frequency band (0.1-70 cycles per day) there were no highly significant peaks, except the diurnal and series-long period in the sea-level record (Fig. 8h). In the horizontal velocity records less reliable signals were in the diurnal period (23-24 h), near-inertial period (13.4-14.3 h), at $3.6 \mathrm{~h}$, and around 9 days (which is actually the length of the time series). The low-frequency band of the spectra possibly reflects diurnal and synoptical changes in atmospheric forcing. Vertical velocities show a rather elevated high-frequency side of the spectra, which "successfully" illustrates the above-discussed 20-30 min periodicity. However, due to the relatively small vertical velocity values versus high noise level, this spectra region should be considered as "white noise". When smoothing 

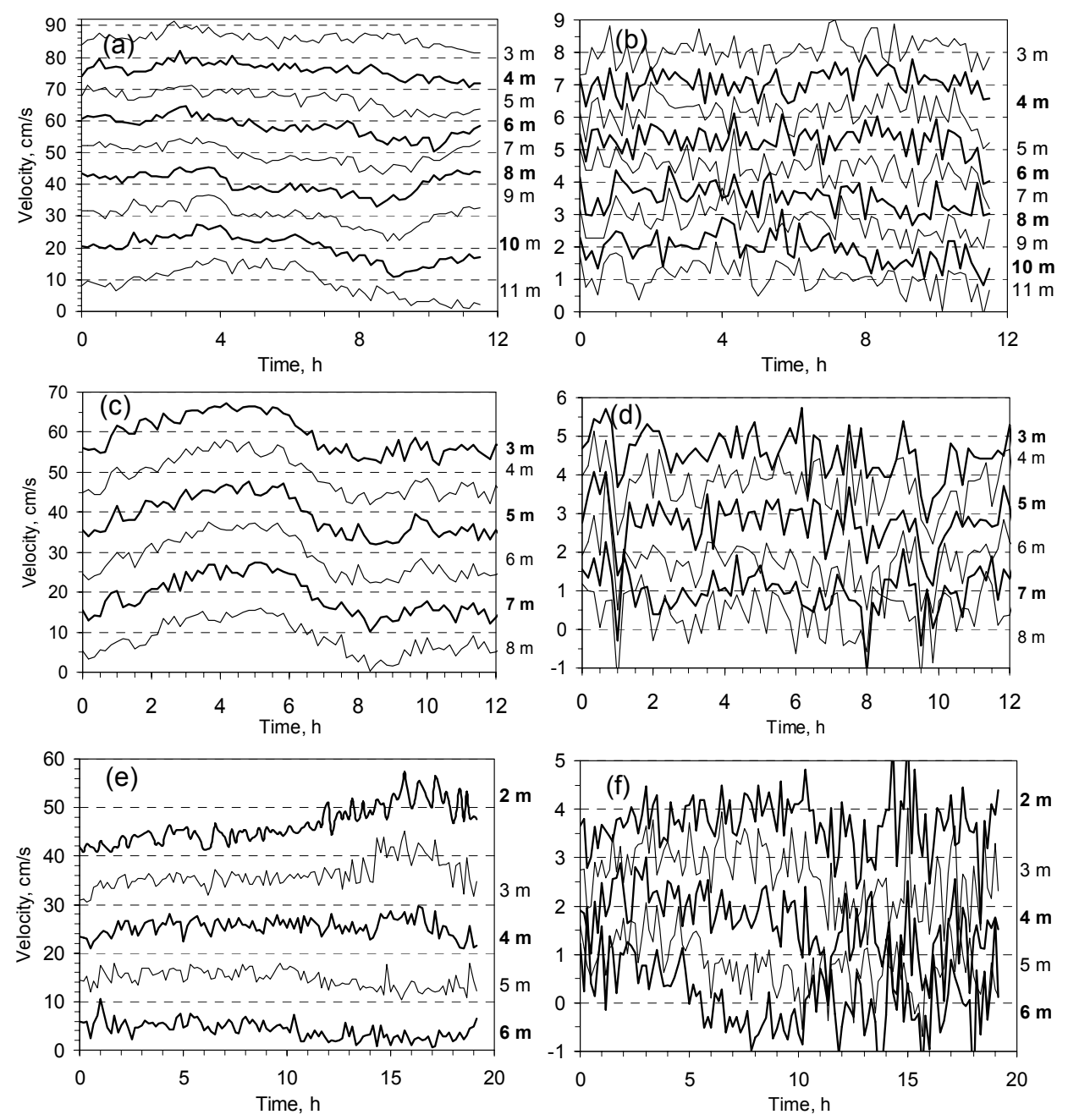

Fig. 7. Fine structure of horizontal velocity modula (a, c, e) and vertical velocities (b, d, f) during the whole periods of the first and the third survey $(a, b, e, f)$ and during the first $12 \mathrm{~h}$ of the second survey (c, d). Offsets of respectively +10 and $+1 \mathrm{~cm}$ are applied to consecutive in depth horizontal and vertical velocity timeseries.

the vertical velocity spectra values, the majority of the graph remains between the confidence intervals of the white noise spectrum line (Fig. 8e, f). Thus, technically the useful statistical information carried by the direct measurements of vertical velocities is considerably smaller than that of horizontal velocities. The scientific value of vertical flow measurements is still large, bearing in mind the decisive role of vertical fluxes in hydrochemical and hydrobiological processes and the rarity of such measurements. 

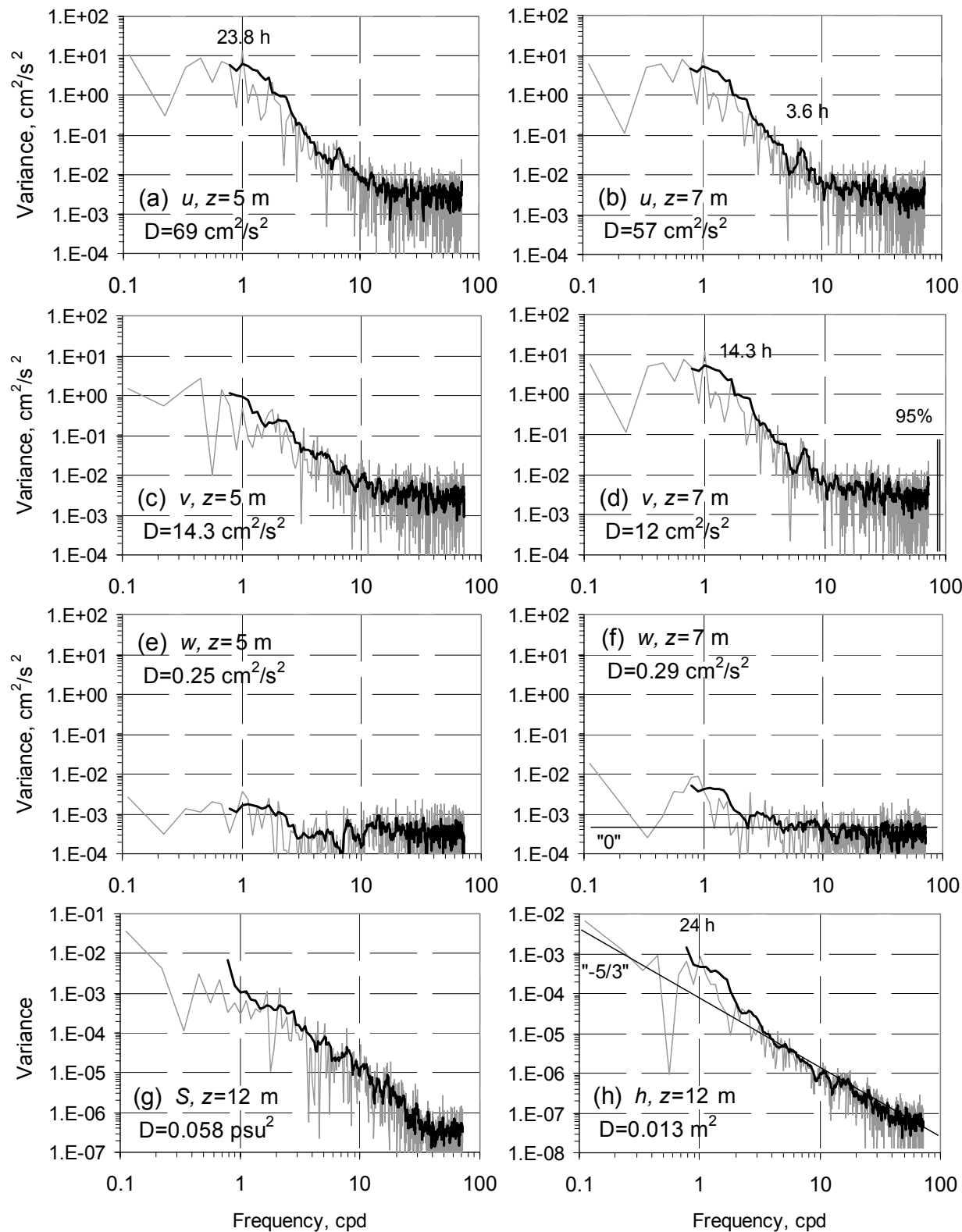

Fig. 8. Fourier spectra of horizontal velocity components $u$ and $v$, and vertical velocity component $w$ at depths $z=5 \mathrm{~m}$ and $z=7 \mathrm{~m} \mathrm{(a-f);} \mathrm{spectra} \mathrm{of} \mathrm{salinity} \mathrm{(g)} \mathrm{and} \mathrm{sea-level} \mathrm{height} \mathrm{(h)} \mathrm{on} \mathrm{27.10}$ 5.11.2003. Nonsmoothed values are shown with grey lines, the corresponding $95 \%$ confidence interval in the case of 1 degree of freedom is marked in (d), smoothed over 7 periods values are shown with black bold lines, the position of the white noise spectrum is shown with " 0 " in (f), spectral decay proportional to power $-5 / 3$ in (h); D - total variance, frequencies in cycles per day (cpd), the periods of some peaks are marked above the graphs. 


\section{CONCLUSIONS}

Direct current velocity measurements using a Doppler current profiler showed considerable variations both in time and in vertical plane. Despite calm weather conditions (average wind speeds 2.1, 3.7, and $1.9 \mathrm{~m} / \mathrm{s}$ during the three measuring periods), the maximum horizontal current velocity reached $37 \mathrm{~cm} / \mathrm{s}$. As all the mooring sites were relatively close to the coast, downwind horizontal transport with relatively small differences over the vertical profile prevailed. In the case of Muuga Bay, this directly wind-driven flow component was affected by the subbasin-wide flow pattern rather than the possible estuarine flow pattern of the Gulf of Finland.

Of the vertical velocity readings $11 \%$ were above $1 \mathrm{~cm} / \mathrm{s}$ or below $-1 \mathrm{~cm} / \mathrm{s}$ and the average modula of vertical velocities were between 0.47 and $0.60 \mathrm{~cm} / \mathrm{s}$, being about 10-20 times smaller than the simultaneous horizontal velocities. However, the vertical velocities do not much exceed the statistical noise level $(0.29 \mathrm{~cm} / \mathrm{s})$ of the instrument. Spectral analysis suggested that only a narrow lowfrequency region (say, periods less than $2 \mathrm{cpd}$ ) of the vertical velocity frequency spectra should be trusted, probably reflecting diurnal and synoptical atmospheric forcing. The fine structure of the vertical velocity time series is likely an artefact.

Higher than expected measured vertical velocities indicate a disagreement with certain theoretical considerations and should be investigated in detail in the future. It is possible that the particles backscattering the RDCP signals were not neutrally buoyant. Assuming that the measurements reflected correctly the velocity field, ecpecially the vertical velocity field, we can conclude that different water layers are not as isolated as only recently suggested. Although the typical up- or downwelling were not the case, our measurements showed that at least above the sloping bottom and within the upper, relatively mixed layer, rapid vertical spread of both hydrochemical and hydrobiological properties is not hydrodynamically restricted.

\section{ACKNOWLEDGEMENTS}

The study was partly supported by the Estonian Science Foundation (through grant No. 5929). The survey at Muuga Bay was supported by the Muuga Bay Monitoring Programme in 2003. The authors acknowledge the help and assistance by Rein Tamsalu, Robert Aps, Mart Saarso, Ivo Saaremäe, Jüri Rauk, Are Kont, Reimo Rivis, and Tanel Ilves. We thank the vessel owners, captains, and the crew members for the help.

\section{REFERENCES}

Andrejev, O., Myrberg, K., Alenius, P. \& Lundberg, P. 2004. Mean circulation and water exchange in the Gulf of Finland - a study based on three-dimensional modelling. Boreal Env. Res., 9, $1-16$. 
Deleersnijder, E. 1989. Upwelling and upsloping in three-dimensional marine models. Appl. Math. Model., 13, 462-467.

Ennet, P., Kuosa, H. \& Tamsalu, R. 2000. The influence of upwelling and entrainment on the algal bloom in the Baltic Sea. J. Mar. Syst., 25, 359-367.

Geyer, W. R. 1993. Three-dimensional tidal flow around headlands. J. Geophys. Res., 98, 955-966.

Hervouet, J.-M. 2003. Solving non-hydrostatic Navier-Stokes equations with a free surface. In Coastal Engineering VI (Brebbia, C. A., ed.), pp. 3-22. WIT Press, Southampton, Boston.

Liljebladh, B. \& Thomasson, M. A. 2001. Krill behaviour as recorded by acoustic Doppler current profilers in the Gullmarsfjord. J. Mar. Syst., 27, 301-313.

Lilover, M.-J., Lips, U., Laanearu, J. \& Liljebladh, B. 1998. Flow regime in the Irbe Strait. Aquat. Sci., 60, 253-265.

Marmorino, G. O. \& Trump, C. L. 1992. Acoustic Doppler current profiler measurements of possible lee waves south of Key West, Florida. J. Geophys. Res., 97, 7271-7275.

Myrberg, K. \& Andrejev, O. 2003. Main upwelling regions in the Baltic Sea - a statistical analysis based on three-dimensional modelling. Boreal Env. Res., 8, 97-112.

Orviku, K., Jaagus, J., Kont, A., Ratas, U. \& Rivis, R. 2003. Increasing activity of coastal processes associated with climate change in Estonia. J. Coast. Res., 19, 364-375.

Raudsepp, U. 1998. Current dynamics of estuarine circulation in the lateral boundary layer. Estuarine, Coastal Shelf Sci., 47, 715-730.

Suursaar, Ü., Kullas, T., Otsmann, M. \& Kõuts, T. 2003. Extreme sea level events in the coastal waters of West Estonia. J. Sea Res., 49, 295-303.

Sobarzo, M., Figueroa, M. \& Djurfeldt, L. 2001. Upwelling of subsurface water into the rim of the Biobio submarine canyon as a response to surface winds. Continent. Shelf Res., 21, 279299.

Zalesny, V. B., Tamsalu, R. \& Kullas, T. 2004. Nonhydrostatic model of marine circulation. Oceanology, 44, 461-471.

Tamsalu, R. (ed.) 2003. Muuga sadama merekeskkonnamõju seire 2003. Tartu Ülikool, Eesti Mereinstituut, Tallinn. Manuscript in the library of the Estonian Marine Institute.

van Haren, H. 2001. Estimates of sea level, waves and winds from a bottom-mounted ADCP in a shelf sea. J. Sea Res., 45, 1-14.

Wewetzer, S. F. K., Duck, R. W. \& Anderson, J. 1999. Acoustic Doppler current profiler measurements in coastal and estuarine environments: examples from the Tay Estuary, Scotland. Geomorphology, 29, 21-30.

Yanagi, T., Ishikawa, K., Inoue, K. \& Susami, S. 1995. Convergence, divergence and vertical velocity at a tidal front in Hiuchi-Nada, Japan. J. Oceanogr., 51, 225-238.

\title{
Horisontaal- ja vertikaalkiiruste vertikaalse struktuuri mõõtmised Eesti rannikumeres Doppleri efektil põhineva hoovustemõõtjaga
}

\author{
Ülo Suursaar, Tiit Kullas ja Mikk Otsmann
}

On uuritud vee liikumise kiiruse kolme komponendi vertikaalset struktuuri Muuga ja Küdema lahes, kasutades 2003. a sügisel ja 2004. a varasuvel hoovustemõõtjaga RDCP 600 saadud tulemusi. Mõõtmisi sooritati kuni üheksas kihis kokku 245 tunni vältel. Vaatamata vaiksetele ilmastikuoludele (keskmine tuule 
kiirus $3,4 \mathrm{~m} / \mathrm{s}$ ), registreeriti hoovuse kiiruseks kuni $37 \mathrm{~cm} / \mathrm{s}$. Et mõõtekohad asusid suhteliselt ranna lähedal, domineeris kõigil kolmel juhul allatuult horisontaalne voolamine väikeste erinevustega vertikaalis. Vertikaalkiiruste absoluutväärtuste keskmised jäid eri mõõteperioodidel vahemikku $0,47-0,60 \mathrm{~cm} / \mathrm{s}$, olles vaid 10-20 korda väiksemad kui samaaegsed horisontaalkiirused. Oodatust mõnevõrra suuremad vertikaalkiirused võivad tähendada, et vähemalt rannanõlva kohal ja ülemises, 10-20 m paksuses kihis, on hüdrokeemiliste ja -bioloogiliste parameetrite vertikaalne migratsioon hüdrodünaamiliselt soodustatud. Teisalt vajaks edasist täpsemat uurimist võimalus, et merevesi sisaldab hulgaliselt selliseid RDCP-signaale tagasipeegeldavaid osakesi, mis liiguvad vee suhtes üles- või allasuunas. 